University of Warwick institutional repository: http://go.warwick.ac.uk/wrap This paper is made available online in accordance with publisher policies. Please scroll down to view the document itself. Please refer to the repository record for this item and our policy information available from the repository home page for further information.

To see the final version of this paper please visit the publisher's website. Access to the published version may require a subscription.

Author(s): Beat Kumin

Article Title: Public houses and civic tensions in early modern Bern Year of publication: 2007 Link to published version: http://dx.doi.org/10.1017/S0963926807004361

Publisher statement: None 


\title{
Public houses and civic tensions in early modern Bern
}

\author{
BEAT KÜMIN* \\ Department of History, University of Warwick, Coventry CV4 7AL
}

\begin{abstract}
This article examines the delicate relationship between the civic privilege of wine retailing and the constitutional emphasis on order in a city republic. Burghers appreciated the revenues from beverage sales, while urban authorities worried about destabilizing effects. In the context of state formation, Bern claimed control over public houses throughout its territory, but closer analysis suggests that socio-economic and political interests were constantly renegotiated, not only within the capital but also between centre and periphery.
\end{abstract}

This article focuses on tensions associated with public houses in the Swiss city republic of Bern. Drinking establishments have attracted growing attention since the 1980s and especially in the course of the recent ascent of the 'new cultural history'. ${ }^{1}$ With regard to social and political repercussions, most studies have focused on two aspects: violence and immoral behaviour associated with alcohol consumption on the one hand, ${ }^{2}$ and the stabilizing potential of neighbourly sociability and sociocultural services on the other. ${ }^{3}$ Much less, however, has been said on wider 'constitutional' issues relating to the public house, even though

* I am grateful to the British Academy for supporting this article in the form of an Overseas Conference Grant.

1 P. Clark, The English Alehouse: A Social History 1200-1830 (London, 1983); T. Brennan, Public Drinking and Popular Culture in Eighteenth-Century Paris (Princeton, 1988); L.A. Martin, Alcohol, Sex and Gender in Late Medieval and Early Modern Europe (Basingstoke, 2001); B.A. Tlusty, Bacchus and Civic Order: The Culture of Drink in Early Modern Germany (Charlottesville, 2001); B. Kümin and B.A. Tlusty (eds.), The World of the Tavern in Early Modern Europe (Aldershot, 2002); B. Kümin, Drinking Matters: Public Houses and Social Exchange in Early Modern Central Europe (Basingstoke, forthcoming).

2 K. Wrightson, 'Alehouses, order and reformation in rural England 1590-1660', in S. Yeo and E. Yeo (eds.), Popular Culture and Class Conflict 1590-1914 (Brighton, 1981), 127; P. Wettmann-Jungblut, 'Gewalt und Gegen-Gewalt: Gewalthandeln, Alkoholkonsum und die Dynamik von Konflikten anhand eines Fallbeispiels aus dem frühneuzeitlichen Schwarzwald', in M. Eriksson and B. Krug-Richter (eds.), Streitkulturen: Gewalt, Konflikt und Kommunikation in der ländlichen Gesellschaft der frühen Neuzeit (16.-19. Jahrhundert) (Cologne, 2003), 17-58; B. Kümin, 'Friede, Gewalt und öffentliche Räume: Grenzziehungen im alteuropäischen Wirtshaus', in C. Ulbrich et al. (eds.), Gewalt in der Frühen Neuzeit (Berlin, 2005), 130-9.

3 Tlusty, Bacchus and Civic Order, 211-12. 
it formed one of the main institutional centres in pre-industrial towns and villages. $^{4}$

This article examines how 'civic liberties' connected to the retailing of alcohol threatened 'urban stability' in early modern Europe. Based on a variety of normative, legal and administrative sources, the argument highlights a range of conflicts involving a neglected category of public houses: not so much formally established inns - offering full catering services including hot meals and overnight accommodation - nor officially approved taverns - usually restricted to the provision of drinks and cold dishes, but 'normal' urban households enjoying customary rights to sell wine or beer to members of the public. The emphasis, therefore, lies on the retailing of alchol based on personal privileges rather than the ownership of licensed premises (although the borderlines are sometimes blurred). The empirical evidence derives from a central European territory comprising both German- and French-speaking areas. As a city-state with a republican constitution and a substantial number of relatively autonomous dependent towns, Bern offers a case study of particular interest for urban historians. ${ }^{5}$ Two (interrelated) levels of tensions can be distinguished: first, conflicts within individual communities and, second, arguments between the ruling capital and subject municipalities within its territory. These shall now be examined in turn, although the available space allows only the briefest of engagements with individual disputes.

\section{Conflicts within communities}

To start with inner-communal conflicts, most of these resulted from diverging priorities among the principal interest groups. Publicans, of course, sold wine to gain or augment their livelihoods; customers looked for victuals, sociability and entertainment at minimal cost; while urban and ecclesiastical authorities worried about the socio-economic and moral implications of high alcohol consumption. Among these concerns, one frequent flashpoint has as yet attracted very little attention: the clash between long-standing alcohol-retailing rights of individual burghers and the town governments' attempts to enhance economic prosperity and promote social discipline in the early modern period.

Bern was an agricultural region characterized by a mixture of arable farming, cattle rearing and fairly extensive viticulture. Vintners - as well as lords and officials who received wine as part of feudal revenues, salaries or tithe income - possessed a 'natural' right to sell their produce in both large and small quantities, even in the countryside. In the district of Nidau (near

${ }^{4}$ B. Kümin, 'Rathaus, Wirtshaus, Gotteshaus. Von der Zwei- zur Dreidimensionalität in der frühneuzeitlichen Gemeindeforschung', in F. Šmahel (ed.), Geist, Gesellschaft, Kirche im 13.16. Jahrhundert (Prague, 1999), 249-62.

${ }^{5}$ For the general context of early modern Bernese history see A. Holenstein (ed.), Berns Mächtige Zeit: Das 16. und 17. Jahrhundert neu entdeckt (Bern, 2006). 
Biel), for example, members of the peasantry had the 'freedom to sell their own wine in small measures from their houses'. ${ }^{6}$ In urban communities throughout the territory, however, the sale of wine was perceived as a prerogative not just of individuals with direct links to viticulture, but of the entire civic body. Sources like town statutes, collections of customary law and registers of public houses provide a wealth of explicit evidence for the ubiquity of this phenomenon.

One or two examples per region may stand for many others here: at Büren in the See- or Mittelland (the area between Bern and Solothurn; see Figure 1), a fourteenth-century town charter contained the passage that 'each burgher was free to sell wine in small measures, whenever he liked'. ${ }^{7}$ Further eastwards in the Bernese Aargau, early modern police ordinances of Brugg gave enfranchised inhabitants particularly extensive privileges, namely to cater for drinkers 'both with their own produce as well as additional wine' bought on the market 'at will' ${ }^{8}$ In the southwestern, French-speaking Pays de Vaud, where most Bernese wine was cultivated - including the superior La Côte and Ryff denominations on the shores of Lake Geneva, practically all municipalities possessed crystal-clear proof of customary retailing rights. ${ }^{9}$ According to territorial registers of drinking houses, visitors to Vufflens-la-Ville found neither licensed premises nor imported brands, but only burghers selling the harvest from their own vineyards, while the Vaud's capital of Lausanne distinguished two types of civic prerogatives: those for habitants (i.e. residents without full political rights), who were only allowed to sell what they had produced themselves, and those for higher-ranking bourgeois, who enjoyed the additional entitlement to stock all the foreign wines that could be legally imported into the city. ${ }^{10}$ Yet viticulture flourished even in the harsher climate of the Alpine Bernese Oberland, especially on the southern banks of Lake Thun. Unterseen, located in the immediate vicinity of the former monastery of Interlaken, possessed written confirmation of its burghers' wine-retailing privileges from the council of Bern in 1582. Rather than exercising these individually, the town had decided to establish six communal taverns - alongside a regular inn within and several public houses just outside its walls - by the late seventeenth century. ${ }^{11}$ The most striking case, however, was the capital city itself. Here,

${ }^{6}$ State Archives of Bern (StAB), B V 143, 35 (1688).

7 Ibid., B V 142, 33 (quoted in a territorial register of public houses of 1628).

8 Ibid., B V 144, 23 (1743); at nearby Wangen in the Upper Aargau, comparable rights dated from a franchise of 1501: ibid., B V 147, 673-5 (reported in 1786).

9 Examples include the towns of Aigle (ibid., B V 144, 3), St Prex (ibid., 66) and Nyon (ibid., B V 147, 1058).

10 Ibid., B V 144, 57 (Vufflens, 1743); 'Bourgeois et habitans ont tous le droit de vendre en détail à pot et à pinte, le Vin de leur crû dans le Territorie, et les Bourgeois tous celui qui a droit d'entrer à Lausanne' (ibid., B V 147, 879; 1786).

11 Sammlung Schweizerischer Rechtsquellen, Abt. 2: Die Rechtsquellen des Kantons Bern (Aarau, 1902-) (RQ), pt 2, vol. 6: Interlaken, 461 (1582), and StAB, B V 143, 15 (1688). For wineretailing rights of the burghers of Thun cf. ibid., B V 144, 105 (1743). 


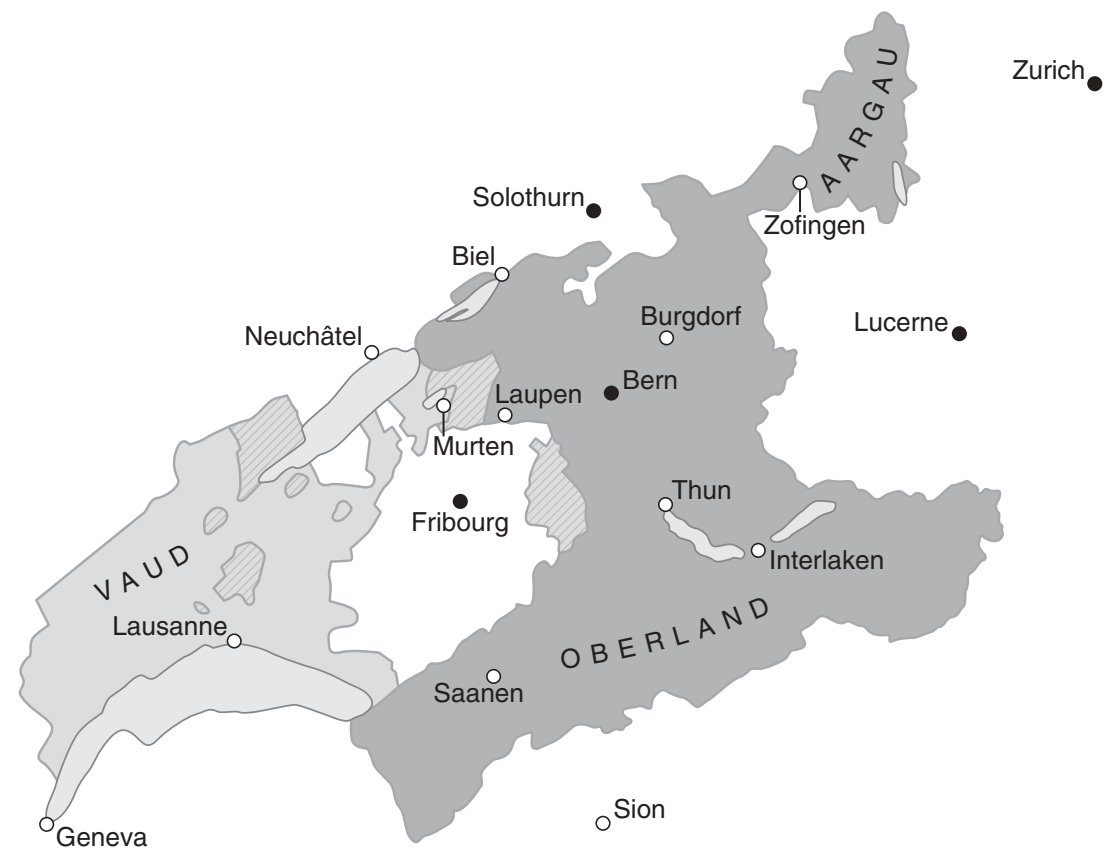

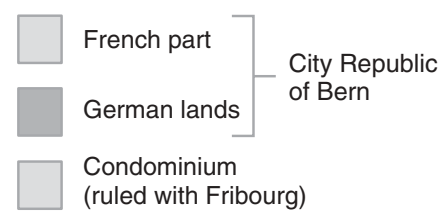

- Capital of Swiss Canton

Figure 1: Map of the City Republic of Bern in the Swiss Confederation (pre-1798 boundaries). The territory was divided into a French part (Pays de Vaud) and the German lands (incl. the See- or Mittelland, i.e. the area between Bern and Solothurn, the Oberland and the Bernese Aargau), both punctuated by semi-autonomous towns such as Burgdorf, Laupen, Lausanne, Thun, Zofingen etc. (C) 2004 Historical Dictionary of Switzerland and Kohli Kartografie, Bern.

patrician prerogatives stretched to a monopoly over the wine trade in the entire Bernese territory, a source of very considerable revenue, given the huge volumes of superior quality crus from the subject Vaud available for consumption and marketing. As has recently been demonstrated for the Effinger family, who owned extensive vineyards in the Aargau, members of the republican elite possessed 'an astonishingly high number of inns 
and taverns' to market their own agricultural produce and whatever they desired to purchase from elsewhere. Patricians did not manage these establishments on a day-to-day basis, of course, but required tenants to obtain all their alcoholic beverages from seigneurial sources. The proceeds of 'noble' public houses were plentiful, contributing up to 50 per cent of the Effinger's total income in certain years. ${ }^{12}$ As for alcohol retailing in the capital itself, an ordinance of 1739 specified that all burghers with full political rights had permission to sell wine in one or several cellars, in fact in as many as they liked', without the need to apply for formal permission. ${ }^{13}$

The impact of these legal customs on everyday urban life was enormous. Provision with licensed establishments alone appears plentiful enough, reaching a ratio of one public house per 300 inhabitants in the Republic of Bern by the late eighteenth century, but the ubiquitous sale of wine by burghers pushed the number of drinks outlets to truly staggering levels. At Unterseen, one inn and six communal taverns catered for a population of some 549 inhabitants in 1764, equivalent to a ratio of 1:78. ${ }^{14}$ At Payerne in 1786, a place with an equally modest population, wine was sold not only in four regular inns, the town hall, a communal tavern, a further establishment subject to a Bernese official and ten civic wine cellars, but also in several private houses. Both the local mayor and the Bernese governor felt that this was excessive, but the burghers insisted that it was their ancient right to sell alcohol in their private dwellings. ${ }^{15}$ More extreme yet was the situation in the capital. Towards the end of the Ancien Régime, around 150 wine cellars lined the streets of a city with a mere 1,000 houses; in other words, alcohol was available for consumption on the premises in every sixth to seventh dwelling. Small wonder that contemporaries coined the saying 'Venice lay on water, but Bern lay on wine. ${ }^{\prime 16}$ On the basis of figures derived from early modern sources - yielding 9 inns, 14 craft hostelries and 145 cellar taverns - and a population estimate of around 11,300 inhabitants by 1798 , the city boasted a ratio of one drink outlet for less than 70 souls and a bewildering amount of choice for locals

12 F. Müller, 'Ownership of public houses by the Swiss nobility: a regional case-study', in Kümin and Tlusty (eds.), World of the Tavern, 177-90, esp. 189-90.

13 Printed in RQ, part 1, vol. 8/1, 235.

14 Kümin, Drinking Matters, ch. 1, table 2 (territorial ratio); the population figure for Unterseen is taken from Anne-Marie Dubler, 'Unterseen', in M. Jorio (ed.), Historisches Lexikon der Schweiz (forthcoming). Similar density of provision has been found at Zofingen (Aargau): F. Müller, 'Wirte und Wirtschaften in Zofingen 1450-1600' (unpublished University of Zurich MA thesis, 1990), 144-5.

15 The burghers argued 'nicht nur in ihren Kelleren, sondern auch in ihren Häüseren Wein ausschenken zu dörffen': StAB, B V 148, 30 (1786).

${ }^{16}$ For context and modern estimates see A. Lechner, 'Etwas von den bernischen Kellerwirtschaften', Neues Berner Taschenbuch (1910), 278-301, and J.H. Wäber, 'Das Gaststättenwesen in der Stadt Bern bis 1798', Berner Zeitschrift für Geschichte und Heimatkunde, 37 (1975), 28. 


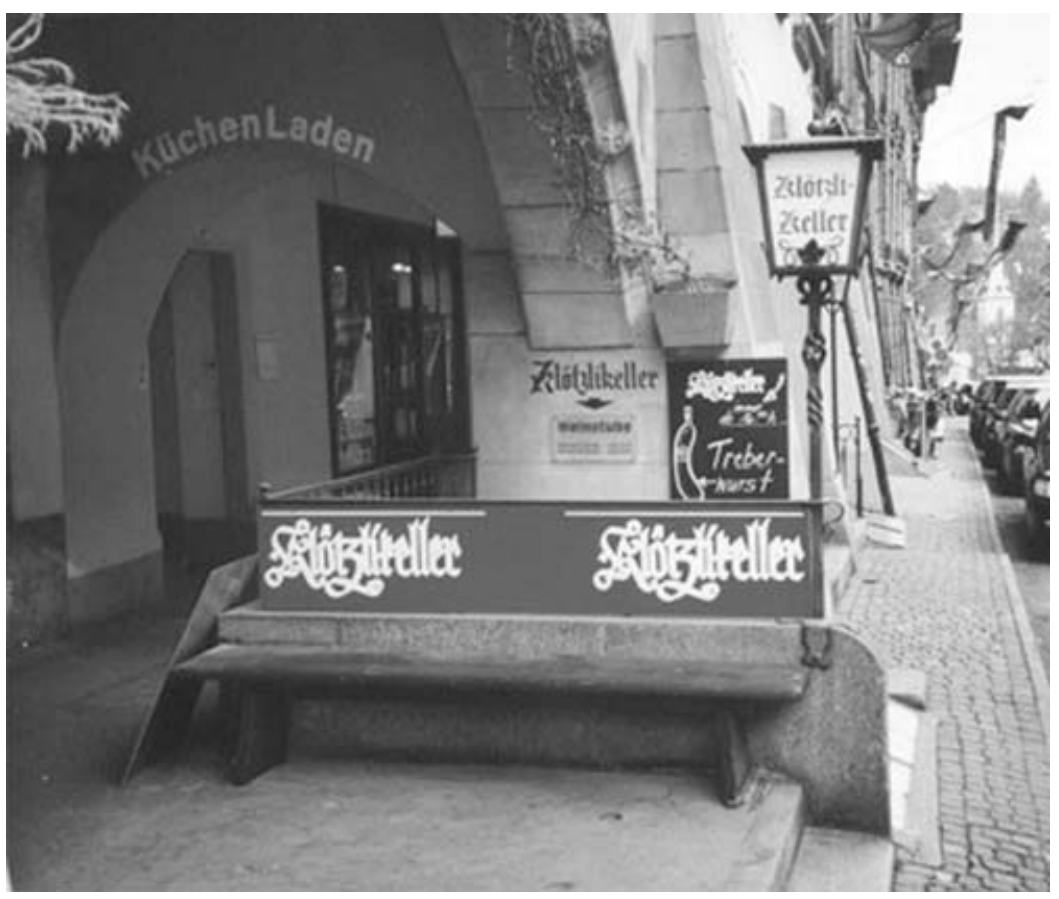

Figure 2: The Klötzlikeller on Gerechtigkeitsgasse is the sole surviving early modern cellar tavern in the City of Bern. According to a (conservative) estimate in Heinzmann, Beschreibung der Stadt und Republik Bern, vol. II, 72, burghers sold wine in 145 such establishments traditionally identified by a pole with fir twigs protruding from the entrance - in the late eighteenth century. In addition, of course, regular inns and craft hostelries vied for custom. Photograph reproduced by kind permission of the 'Leist der untern Stadt Bern'.

as well as visitors (Figure 2). ${ }^{17}$ On top of licensed and customary civic provision, furthermore, many towns granted additional catering rights at times of extraordinary demand. In the small market of Laupen near Bern five artisans -including the butcher Johannes Schlatter - were allowed to set up temporary outlets during the spring and autumn fair of 1753 . Some time later they accounted for a turnover of no less than 2,200 litres, about a quarter of what the regular Bear inn used over a whole year. ${ }^{18}$

17 Figures from StAB, B II 692 (inns); J.R. Gruner, Deliciae urbis Bernae: Merckwürdigkeiten der hochlöblichen Stadt Bern (Zurich, 1732), 420 (guild halls); J.G. Heinzmann, Beschreibung der Stadt und Republik Bern: Nebst vielen nützlichen Nachrichten für Fremde und Einheimische, 2 vols. (Bern, 1794-96), vol. II, 72 (cellar taverns); population estimate from the historical database 'BernHist' (http://www.bernhist.ch).

18 StAB, A V 1114, fols. 80v-81r. 
These circumstances produced serious conflicts of interests: with their 'entrepreneurial' hats on, urban elites endeavoured to sell as much wine as possible, while potential threats to health, welfare and public order worried them in their capacity as political rulers. Such fears were not unfounded, as alcohol consumption could be linked to significant proportions of economic hardship, violent crime and political subversion. In the preamble to the first territorial register of public houses in 1628, the Bernese council argued that these establishments were 'the chief cause of the ruin and impoverishment of our people' and that numbers thus needed to be curbed 'so that they will find less occasion for superfluous eating and drinking, the daily wasting of resources, as well as the ensuing immoral and excessive behaviour'. ${ }^{19}$ This was more than just scaremongering, as numerous urban case studies have shown: almost a fifth of violent crimes in early modern Cologne took place in public houses and around a third of all cases of verbal and/or physical attacks had an explicit connection to drinking establishments in eighteenth-century Frankfurt am Main. ${ }^{20}$ During the Swiss Peasants' War of 1653, meanwhile, inns accommodated both rebel assemblies (for example, Stefan Lötscher's inn at Schüpfheim in Lucerne on 10 February 1653 - ironically also the venue for the local court) and military headquarters (the White Cross at Langenthal for the peasants' 'general' Niklaus Leuenberger in the middle of May). Due to their contacts, resources and public standing, publicans had the required 'cultural capital' to become leaders of such movements. ${ }^{21}$

In many ways, unlicensed premises were more likely to cause trouble, as they lacked the official quality and external monitoring associated with regular inns and taverns. At Büren an der Aare in 1626, a local functionary reported that most citizens handled their privilege in a responsible manner, selling a mere one or two barrels of wine in the autumn, but that some had disregarded opening hours and allowed disorderly behaviour. He assured the Bernese authorities that such people had been punished and that 'moderation and restriction' would be observed in the future. ${ }^{22}$ The 1739

${ }^{19}$ Cited in RQ, pt 1, vol. 8/1, 209. Bernese consistory courts issued warnings and ultimately formal tavern-bans against male householders whose drinking habits endangered their family economies: examples in H.R. Schmidt, Dorf und Religion: Reformierte Sittenzucht in Berner Landgemeinden der frühen Neuzeit (Stuttgart, 1995), 260 n. 150.

${ }^{20}$ G. Schwerhoff, Köln im Kreuzverhör: Kriminalität, Herrschaft und Gesellschaft in einer frühneuzeitlichen Stadt (Bonn, 1991), 294ff; J. Eibach, Frankfurter Verhöre: Städtische Lebenswelten und Kriminalität im 18. Jahrhundert (Paderborn, 2003), 221 (22.2\% of offences took place in public houses and a further $11.1 \%$ after drinkers had spilled out on to the streets). See also B. Müller-Wirthmann, 'Raufhändel: Gewalt und Ehre im Dorf', in R. Van Dülmen (ed.), Kultur der einfachen Leute (Munich, 1983), 79-111; Kümin, 'Gewalt', 138, and the references cited in $n .2$ above.

${ }^{21}$ For the wider context see A. Holenstein, 'Der Bauernkrieg von 1653 - Ursachen, Verlauf und Folgen einer gescheiterten Revolution', Berner Zeitschrift für Geschichte und Heimatkunde, 66 (2004), 1-43; the reference to Langenthal in Berner Zeitung (22 Apr. 2003), 29; on the situation at Schüpfheim: A. Suter, Der schweizerische Bauernkrieg von 1653: Politische Sozialgeschichte - Sozialgeschichte eines politischen Ereignisses (Tübingen, 1997), 140, 510.

22 StAB, B V 141, 45-6. 
ordinance, which has already been referred to, insisted that unlicensed retail sales by citizens should be restricted to wine tapped from standard barrels in clearly marked cellars (typically identified by a pole with fir twigs visible from the street), 'but not secretly in bottles or in back rooms and hidden dens', where all sorts of people could meet in an unsupervised manner. $^{23}$

Matters were complicated further by the very substantial revenues from indirect taxes, which formed a key pillar of state finance in many early modern cities. Ohmgeld or Umgeld, as dues on alcoholic beverages were known in German-speaking areas, emerged in the late Middle Ages, usually as a result of princely privileges or in connection with costly projects such as the construction of city walls. ${ }^{24}$ At Augsburg in the Holy Roman Empire, proceeds from this fiscal device yielded on average over 50 per cent of city income between 1550 and 1650, and in peak years well over two-thirds. Small wonder that the council considered them 'crucial to the survival of the city'. Here as elsewhere, heavy drinking effectively became a service to the common weal. ${ }^{25}$ From the consumer's perspective, tax added between 3 and 25 per cent to the price of a measure of beer or wine, depending on location, time and the condition of state finances. Most tipplers paid around 5 per cent, but in extreme circumstances - as at Augsburg during the Thirty Years War - prices could double. ${ }^{26}$

Administrative and legal records testify to the delicate balancing of these conflicting concerns in countless specific conflicts, whether it concerned supplementary wine imports from abroad or the applicability of civic privileges to properties located outside the city walls. ${ }^{27}$ Adding the religious and moral campaign against irresponsible alcohol consumption

${ }^{23} \mathrm{RQ}$, part 1, vol. 8/1, 237.

${ }^{24}$ In 1436, for example, Duke Ernst of Bavaria granted the market of Dachau the right to levy indirect taxes for the construction of a castle in the town: G. Hanke et al., Geschichte des Marktes und der Stadt Dachau (Dachau, 2000), 40; in 1488, the priory of Herzogenbuchsee near Bern exercised similar powers within its jurisdiction: RQ, pt 2, vol. 10, 183-4. Specifically on Bern see H. Braun, 'Die Ungeld- und Böspfennigrechnungen der Stadt Bern 1686/87-1692/93' (Seminar paper, University of Bern, 1990).

25 Tlusty, Bacchus and Civic Order, 177 (Augsburg). In a sample of 35 case studies 1370-1622, the share of town income from taxes on beer varied between $4.6 \%$ (Hamburg 1370) and a staggering 88.5\% (Haarlem 1437): R.W. Unger, Beer in the Middle Ages and the Renaissance (Philadelphia, 2004), 197; in the Swiss Confederation, customs and taxes on victuals chiefly wine - accounted for $14-28 \%$ of total state revenues in the fifteenth century and 10$27 \%$ in the eighteenth, with (wealthy) Bern at the bottom end of the scale: M. Körner, 'The Swiss Confederation', in R. Bonney (ed.), The Rise of the Fiscal State in Europe (Oxford, 1999), 327-57, esp. 345. On Bernese state finance in general see now S. Altorfer, 'State building without taxation: the case of eighteenth-century Bern' (unpublished London School of Economics Ph.D. thesis, c. 2006).

${ }^{26}$ Percentage range based on examples given in T. Scott, 'Medieval viticulture in the Germanspeaking lands', German History, 20 (2002), 95-115, esp. 108; Tlusty, Bacchus and Civic Order, 248 n. 78; Unger, Beer, 244 (excise tax making up a staggering $86 \%$ of the beer price at Lier 1698).

27 See the collection of relevant materials in RQ, pt 1, vol. 8/1. In 1688, the Bernese patricians Mey, Diessbach and Muralt unsuccessfully argued that the civic privilege of unrestricted wine retailing rights applied also to their rural manors: StAB, B V 143, passim. 
by an austere Zwinglian clergy, it is obvious that the public house formed a prominent bone of contention in Bernese social and political life. ${ }^{28}$

\section{Conflicts between centre and periphery}

Moving to the second part of the argument, we have already seen how central authorities worried about the moral dangers of heavy alcohol consumption. From the close of the Middle Ages, therefore, the emerging 'state' took an ever more active role in the supervision of the drinks trade. Like princes and city fathers elsewhere, the Bernese council sought to regulate public houses in ever more detail and, above all, to gain control over the number of retail outlets throughout its vast territory. ${ }^{29}$ This external interference added a new dimension to alcohol-related disputes in early modern towns. Publicans and vintners, as well as individual burghers, now frequently appealed to representatives of the state to defend their interests. One near-permanent source of tensions was the intense competition within the trade. Plentiful supply was appreciated during busy periods, but a cause for concern in everyday urban life. One case study may illustrate how intensely the various parties fought over a limited pool of customers.

Laupen, originally an Imperial Free City, came under Bernese lordship in 1324 and subsequently served as the centre of an administrative district on the border with Catholic Fribourg. In the eighteenth century, it had at most 300 inhabitants, but a respectable urban infrastructure including two fairs, shops and - according to official registers - one inn (the Bear) plus one or two taverns (including the Cross). ${ }^{30}$ The Bernese governor's correspondence with his superiors, however, reveals that catering provision was anything but static. On top of running temporary outlets during fairs, burghers also enjoyed the 'liberty ... to sell wine in their cellars' ${ }^{31}$ The exact form and extent of this privilege caused no end of disputes, particularly in the early and mid-1600s. In 1622, Hans Lässer one of the regular publicans - alerted the governor to the emergence of an (informal) communal tavern in the town hall, which made little effort to observe trading regulations. The local minister, who lived in the immediate vicinity, was equally concerned, not least because noise levels stopped him from studying and preparing his sermons. ${ }^{32}$ The

28 A long-term quantitative case study of the impact of Zwinglian discipline on Bernese parishes in Schmidt, Dorf und Religion.

29 For the wide spectrum of relevant regulation see J. Hunter, 'English inns, taverns, alehouses and brandy shops: the legislative framework, 1495-1797', in Kümin and Tlusty (eds.), World of the Tavern, 65-82, and - for Bern - RQ, passim (esp. pt 1, vol. 8/1).

30 T. Beyeler, Laupen (Bern, 1989), 17 (population) and passim (history). For the town's infrastructure B. Kümin and A. Radeff, 'Markt-Wirtschaft: Handelsinfrastruktur und Gastgewerbe im alten Bern', in Schweizerische Zeitschrift für Geschichte, 50 (2000), 1-19, esp. 4.

31 StAB, B V 148, 8 (1789).

32 Ibid., A V 1111, 333-4. 
central authorities instructed the governor to enforce the law and stop all illegitimate sale of wine, but this was easier said than done. In 1656, at the time of the so-called Villmergen civil war between Catholic and Reformed cantons of the Swiss Confederation, the situation got completely out of hand. Governor Stephan Perreth reported that 'nearly everybody' attempted to run their own tavern. At least three or four informal outlets competed with the established publicans, a situation threatening to 'cause burghers and peasants much damage and ruin'. Hans Balmer, keeper of the Cross, thus appealed to the council, complaining that 'during the war many people had started to offer food and drink to the public' and continued to do so 'to the great detriment of his own establishment'. Bern's 'gracious lords' re-emphasized that all unapproved outlets should be abolished, but they fought a losing battle. ${ }^{33}$ At one point, in fact, even their own governor attempted to sell tithe wine not just in his castle, as appropriate for a government official, but also in the town centre, which caused a storm of popular protest. ${ }^{34}$ By the late eighteenth century, an 'enlightened' description of the district still pointed to the proliferation of wine outlets and the inhabitants' addiction to drink as obstacles to the area's improvement, with the city of Laupen singled out for particular blame. $^{35}$

For local communties, central authorities were both a resource (as potential champions of particular interests) and a threat (to the cherished principle of local autonomy). What was at stake for burghers was the defence of their own political power in the context of early modern state formation. Urban privileges to license and supervise public houses emerged as something of a test case. Many towns had good evidence to back up their claims. In 1743, Nidau produced an 'extract of a charter issued by their gracious lords on 3 February 1448 in which [the town] was permitted to choose and dismiss innkeepers, taverners as well as butchers' and, in 1786, it added confidently that these rights were exercised 'without our [the Bernese council's] and our governor's involvement'. ${ }^{36}$ The customs of the Pays de Vaud, collated and published in 1730, also

33 Ibid., 347 (complaints), and ibid., A II 436, 133 (council decision of 10 Mar. 1656). In 1661 , publicans Balmer and Ruprecht (from the Cross and Bear respectively) alerted the governor to substantial wine sales by the smith Jacob Klopfstein, which proved 'to their greatest damage and disadvantage', assuring the official that they would keep their own establishments well stocked with good and inexpensive wines and victuals: ibid., A V 1111, 355 . The case dragged on for several years and the defendant proved 'entirely disobedient' (ibid., 361).

34 Ibid., A V 1113, 9 (ministers and officials only allowed to sell their own wine in castles and rectories; 1665); following complaints by the burghers of Laupen about the governor's action, the prohibition was confirmed by the council of Bern in 1735 (ibid., pp. 13-18).

35 N.A.R. Holzer, Beschreibung des Amtes Laupen 1779, ed. Hans A. Michel (Bern, 1984), esp. $44-5,49$.

36 StAB, B V 144, 74 (1743); explicitly 'ann unser und unsers Vogts bÿ ihnen ÿntrag': ibid., B $\mathrm{V} 147,289$. The town authorities of Payerne, too, approved taverns and wine cellars on the basis of their 'droit de tavernage': ibid., B V 144, 86 (1743). 
stated unambiguously:

The council of each town can ... permit all those it perceives to be good, appropriate and able to ... keep a public tavern and inn with a sign and, conversely, to prohibit those who misuse and abuse the right: so that noone shall interfere with the wish to hold inns or taverns without the permission and license of the said councils: while, at all times, the council and burghers of each locality will be careful to prevent any excess and disorder. ${ }^{37}$

Other communities exercised similar authority on less secure grounds. On the occasion of a periodic review of public houses in 1743, Mont la Ville in the Jura mountains admitted that it had 'neither title nor right' for its drinking establishments, but that the odd tavern had been tolerated because of the volume of travellers passing through on their way to Burgundy, while the burghers of the tiny town of Faoug on Lake Morat derived licensing powers from a letter by Bernese officials, although on closer inspection - the latter actually referred to taxation matters and 'contained not a single word' on the subject of retail sales. ${ }^{38}$

Summarizing the overall trend, scholars have sketched a more or less linear increase in central powers over the early modern period. In his pioneering study, Moritz von Stürler argued that from 1628 - the date of a key mandate on public houses - territorial sovereignty replaced communal and manorial powers. ${ }^{39}$ A detailed examination of centreperiphery relations, however, results in a more complex picture. Territorial authorities certainly acquired a growing number of public houses (partly as a result of the great transfer of property during the Reformation) and there was also a clear political will to get a firmer grip on the hospitality trade through legislative measures. In 1707, for example, the council reasserted that 'neither inferior officials nor local communes were authorized to licence taverns' and, in 1715, it clarified that this 'regal' right pertained only to the highest republican body. ${ }^{40}$ Yet in practice, ancient local privileges could not simply be swept away. When the governing body learnt (during one of the many seventeenth-century disputes) that the burghers of Laupen claimed a time-honoured right to elect publicans, it resolved not to 'alter anything' against this practice. There was also little that could be done about the customary Umgeld collection by the town's own officials. ${ }^{41}$

37 LES LOIX ET STATUTS DU PAIS DE VAUD ET LES PRINCIPALES ORDONNANCES \& MANDATS SOUVERAINS, aveC Un répertoire trés exact (Berne, 1730), 28-31.

38 StAB, B V 144, 40 (Mont la Ville); ibid., 114 ('von dem Recht deß Wein außschenkens ist kein Wort darinnen': Faoug).

39 'Die konzessionierten Wirtschaften im Kanton Bern', Berner Zeitschrift für Geschichte und Heimatkunde, 37 (1975), 19-27, esp. 19. Similarly M. Escher, Das Recht des Gastgewerbes im alten Bern (Fribourg, 1977).

40 StAB, A II 615, 456 (1707); ibid., A II 651, 134-5 (1715).

41 Ibid., A II 451, 215-16 (election claim 1661); Gemeindearchiv Laupen, No. 043, 42-3 (right to collect the Umgeld). Other towns like Moudon and Lucens in the Vaud also levied indirect taxes on wine: StAB, B V 148, 26 (1789). Further examples in Braun, 'Ungeld', 14. 
The overall impression is thus one of external advice, interference and mounting pressure rather than a simple transfer of powers to the centre. In the case of Nidau, where - as we have heard - communal rights were pretty watertight, Bern's 'gracious lords' acknowledged that publicans were elected by the burghers, but made it equally clear that there should be no further expansion in the number of drinking establishments. ${ }^{42}$ Similar admonitions were issued to the town of Zofingen, ${ }^{43}$ while at Thun the government insisted that the burghers should import no wine from the Vaud as long as local produce remained available. ${ }^{44}$ As at Faoug, furthermore, alleged local privileges were not simply taken for granted, but carefully scrutinized. With regard to Coppet on Lake Geneva in the mideighteenth century, for example, the territorial lords rejected the town's reference to a right to license further inns as unfounded and ordered it to respect the interests of existing establishments. ${ }^{45}$

In spite of sustained efforts, Bern's ruling council never really obtained total control over public houses in its territory. As late as 1787, the governor of the district of Vevey, at the heart of the wine-growing Vaud region, urged his superiors to take the 'most drastic measures to tackle the ever growing vices and evil' associated with the tavern trade. In his view, he elaborated, it undermined the 'common good', 'as each burgher and peasant arbitrarily sold wine, which threatened good manners and public safety; under the pretext of offering their own produce, many created hidden dens' where crime and gluttony flourished. ${ }^{46}$

\section{Conclusions}

The evidence discussed in this article allows some general conclusions. First, with regard to tavern studies in a narrower sense, we have seen that public houses - ranging from a vintner's living room right up to purpose-built premises in a superior inn - were not just important social centres (with disruptive as well as stabilizing functions), but also frequent objects of political and constitutional disputes, both within individual urban communities and between governing capitals and dependent towns. Second, with a view to broader scholarly debates on early modern state building and social discipline, the case study underlines the limits and contested nature of both of these processes. Wearing many different hats, Bernese rulers steered a delicate and somewhat inconsistent course in tavern policy. Even members of the elite acknowledged that the large number of patrician wine cellars and the booming alcohol trade were hard

\footnotetext{
42 StAB, B V 143, 34 (1688).

43 Ibid., B V 142, 38 (1628); B V 143, 29 (1688).

44 Ibid., B V 144, 105 (1743).

45 Ibid., B V 147, 1075-6, 1087-91.

46 Ibid., B V 147, 1186-7 ('entferte Schlupf Winkel').
} 
to reconcile with persistent calls for moderation. ${ }^{47}$ In addition, like every other 'police state', Bern struggled with the enforcement of its growing body of legislation and the reliability of local officials. ${ }^{48}$ More specifically for a Swiss republic, local autonomy and the defence of long-standing privileges by urban communities turned early modern politics into a constant process of consultation and negotiation. In spite of all centralizing and moralizing tendencies, civic liberties were successfully defended, even in a highly contested area like public houses.

47 Heinzmann, Beschreibung der Stadt und Republik Bern, vol. II, 227, citing from a tract by Bern's Oekonomische Gesellschaft of 1766.

48 For the debate on enforcement issues see J. Schlumbohm, 'Gesetze, die nicht durchgesetzt werden - ein Strukturmerkmal des frühneuzeitlichen Staates?', Geschichte und Gesellschaft, 23 (1997), 647-63, and A. Landwehr, Policey im Alltag: Die Implementation frühneuzeitlicher Policeyordnungen in Leonberg (Frankfurt, 2000), esp. 311. 